\title{
Zika virus: Where to from here?
}

\author{
P K Muchaal ${ }^{1 *}$
}

\section{Abstract}

After the waves of reported cases of infection with Zika virus swept across the Americas in 2015-16, the overall transmission of the virus in the Western Hemisphere declined in 2017. Between June 8 and August 31, 2017, only 16 new cases of Zika virus infection, all travel-related, were reported in Canada. This represents an $88 \%$ reduction in the cases recorded during the same time frame in 2016. Herd immunity undoubtedly constrains the transmission of the virus in endemic regions. However, while most countries in the Americas are no longer observing continuous transmission in the form of sustained increases over time, some areas are experiencing a notable resurgence. Zika virus, in the wake of dengue, West Nile and chikungunya, has become one of the globalized emerging infections-proliferating beyond previously restricted geographic zones. Zika virus is no longer deemed a global health crisis but the virus' unique potential to cause neurological anomalies in fetuses remains a significant concern.

\section{Affiliation}

${ }^{1}$ Centre for Food-borne and Zoonotic Infectious Diseases, Public Health Agency of Canada, Guelph, ON

*Correspondence: pia.muchaal@ canada.ca

Suggested citation: Muchaal PK. Zika virus: Where to from here? Can Commun Dis Rep. 2018;44(1):27-8.

https://doi.org/10.14745/ccdr.v44i01a06

After the waves of reported cases of infection with Zika virus swept across the Americas in 2015-16, the overall transmission of the virus in the Western Hemisphere declined in 2017, likely due to a combination of herd immunity and enhanced mosquito-control campaigns. The decrease in Zika virus transmission was reflected in the concomitant reduction in number of travel-related Zika cases reported by health authorities including the Public Health Agency of Canada (1), the Centers for Disease Control Prevention (2), the European Centre for Disease Prevention and Control $(3,4)$ and the Pan American Health Organization (5).

Between June 8 and August 31, 2017, only 16 new cases of Zika virus infection, all travel-related, were reported in Canada. This represents an $88 \%$ reduction in the cases recorded during the same time frame in 2016. In the continental United States of America (USA), 225 travel-related Zika infections were reported as of October 11, 2017, compared to a total of 5,259 infections in travelers returning from affected regions in 2016 (2). Cases related to locally-acquired vector-borne transmission on the mainland USA also decreased notably: one locally-acquired mosquito borne infection was reported in 2017 (provisional data) versus 225 vector-borne endemic cases in 2016 (2). Similarly, surveillance data from countries in the European Union and European Economic Area (EU/EEA) exhibited a steep decline in the number of confirmed cases in travelers returning from the Caribbean, Central and South America in the latter part of 2016 and into 2017 (3). As of August 29, 2017, no locally-acquired cases by vector-borne transmission were detected in EU/EEA member states (5). The absence of Aedes aegypti, restricted distribution of the European Aedes albopictus and current environmental conditions limit the risk of transmission of Zika virus in the European Union $(3,4)$.

Herd immunity undoubtedly constrains the transmission of the virus in endemic regions; however, transmissibility of the Zika virus, like other vector-borne disease, is associated with spatial heterogeneity (regional variations in mosquito concentrations), driven by seasonal changes in Aedes abundance and local temperatures that affect vector competence (i.e., the ability of this mosquito to acquire, maintain and transmit the Zika virus). The characteristics of the exposed population (e.g., housing and other socioeconomic factors) further determine the fraction of the population exposed to the vector (6). The complex interactions of these variables contribute to a decline or increase in infection rates relative to the immune status of the host population.

While most countries in the Americas are no longer observing continuous transmission in the form of sustained increases over time, some areas are experiencing a notable resurgence of autochthonous cases and new geographical places where infection is transmitted (7). Approximately $50 \%$ of the confirmed cases in Mexico reported between January and August 2017 occurred in three geographical areas where previously only minimal activity had been documented (5). In the early months of this year, Ecuador reported an increase in Zika virus cases in 2017, resulting in a distinctive second wave after the number of cases declined in mid-2016 (8). In Peru, a surge of infections resulted in 800 cases reported to Pan American Health Organization (PAHO) at the peak of the outbreak in March 2017, a four-fold increase over the peak in 2016 (9). Argentina reported sporadic Zika cases in 2016, followed by an increasing trend of confirmed cases in 2017 between January (26 cases) and April (63 cases). By August 31, 2017, Argentina had confirmed 276 cases of Zika virus to PAHO (10).

Zika virus has been present in Africa for over 60 years. In Asia, the virus was first discovered in 1966 and is known to have been circulating in Cambodia, the Republic of Laos and Vietnam prior to 2015. In Southeast Asia, only Singapore experienced an epidemic of Zika virus (11). Outbreaks of equivalent magnitude to that seen in the Americas were not detected across either continent, despite the globalization of travel, the presence 
of permissive mosquito vectors and favourable ecological conditions for transmission. Although evidence from a recent study in Singapore indicated that Zika virus can be easily introduced into a region with good baseline vector control, it is yet unknown whether Asia is at risk of a major Zika epidemic (11).

Zika virus, in the wake of dengue, West Nile and chikungunya, has become one of the globalized emerging infectionsproliferating beyond previously restricted geographic zones. Zika virus is no longer deemed a global health crisis but the virus' unique potential to cause neurological anomalies in fetuses remains a significant concern. While the risk to Canadians is predominantly related to travel to affected areas, the potential impact of climate change on invasive mosquito species inclusion and establishment in Canada needs to be informed by ongoing surveillance and research.

\section{Conflict of interest}

None.

\section{References}

1. Tataryn J, Vrbova L, Drebot M, Wood H, Payne E, Connors $S$ et al. Travel-related Zika virus cases in Canada: October 2015- June 2017. Can Commun Dis Rep. 2018;44(1):18-26. https://www.canada.ca/fr/sante-publique/services/rapportspublications/releve-maladies-transmissibles-canada-rmtc/ numero-mensuel/2018-44/rmtc-volume-44-1-4-janvier-2018/ virus-zika-2015-2017.html

2. Centers for Disease Control. Cumulative Zika Virus Disease Case Counts in the United States, 2015-2017. https://www. cdc.gov/zika/reporting/case-counts.html. [Accessed October 12, 2017].

3. Spiteri G, Sudre B, Septfons A, Beauté J; On Behalf Of The European Zika Surveillance Network. Surveillance of Zika virus infection in the EU/EEA, June 2015 to January 2017. Euro Surveill 2017 Oct;22(41): DOI (http://dx.doi. org/10.2807/1560-7917.ES.2017.22.41.17-00254). PubMed (https://www.ncbi.nlm.nih.gov/entrez/query.fcgi?cmd=Retrie ve\&db=PubMed\&list_uids=29043960\&dopt=Abstract).
4. European Centre for Disease Prevention and Control. Rapid risk assessment. Zika virus disease epidemic. 10th update, 4 April 2017. Stockholm: ECDC; 2017.

5. European Centers for Disease Prevention and Control. Communicable Disease Threats Report (CDTR), Week 35, 27 August-2 September 2017. https://ecdc.europa.eu/sites/ portal/files/documents/Communicable-disease-threatsreport-2-sep-2017.pdf. [Accessed October 12, 2017].

6. Zhang Q, Sun K, Chinazzi M, Pastore Y Piontti A, Dean NE, Rojas DP et al. Spread of Zika virus in the Americas. Proc Natl Acad Sci USA 2017 May;114(22):E4334-43. DOI (http:// dx.doi.org/10.1073/pnas.1620161114) PubMed (https:// www.ncbi.nlm.nih.gov/entrez/query.fcgi?cmd=Retrieve $\& \mathrm{db}=$ PubMed\&list_uids=28442561\&dopt=Abstract).

7. Pan American Health Organization/World Health Organization. Regional Zika Epidemiological Update (Americas) August 25, 2017. Washington (DC): PAHO/WHO; 2017. http://www.paho.org/hq/index.php?option=com_con tent\&view=article\&id=11599:regional-zika-epidemiologicalupdate-americas\&ltemid=41691 [Accessed October 12, 2017].

8. Pan American Health Organization/World Health Organization. Zika-Epidemiological Report Ecuador. September 2017. Washington (DC): PAHO/WHO; 2017 http://www.paho.org/hq/index.php?option=com docman\&task=doc_view\&gid=35027\&ltemid=270\&lang=en. [Accessed October 16, 2017].

9. Pan American Health Organization/World Health Organization. Zika-Epidemiological Report Peru. September 2017. Washington (DC): PAHO/WHO; 2017 http://www. paho.org/hq/index.php?option=com_docman\&task=doc_vi ew\&gid=35138\&ltemid=270\&lang=en. [Accessed October 16, 2017].

10. Pan American Health Organization/World Health Organization. Zika Cumulative Cases. [Argentina] http:// www.paho.org/hq/index.php?option=com_content\&vie $\mathrm{w}=$ article\&id=12390\&ltemid=42090\&lang=en. [Accessed October 16, 2017].

11. Singapore Zika Study Group. Outbreak of Zika virus infection in Singapore: an epidemiological, entomological, virological, and clinical analysis. Lancet Infect Dis 2017 Aug;17(8):813-21. DOI (http://dx.doi.org/10.1016/S14733099(17)30249-9). PubMed (https://www.ncbi.nlm.nih. gov/entrez/query.fcgi?cmd=Retrieve\&db=PubMed\&lis t_uids=28527892\&dopt=Abstract). 